\title{
EFFICIENCY OF FOUR DISINFECTANTS AGAINST EIMERIA TENELLA ISOLATES FROM EGYPTIAN CHICKENS (IN VITRO ASSESSMENT)
}

\author{
SHIEM EL-SHERRY ${ }^{1}$; MOHAMED A. ALY ${ }^{1}$; MOHAMED A. SOLIMAN ${ }^{2}$; \\ MADEHA DARWISH ${ }^{3}$ AND OMAR AMEN ${ }^{1}$ \\ ${ }^{1}$ Poultry Diseases Department, Faculty of Veterinary Medicine, Assiut University, \\ Assiut 71526, Egypt \\ ${ }^{2}$ Poultry and Fish Diseases Department, Faculty of Veterinary Medicine, Al Minia \\ University, Al Minia 61519, Egypt. \\ ${ }^{3}$ Department of Animal and Poultry Behavior and Management, Faculty of Veterinary Medicine, Assiut \\ University, 71526, Egypt.
}

Received: 5 April 2021; Accepted: 30 April 2021

\begin{abstract}
Background: Control of coccidiosis depends, in addition to the commercial preparation of herbal extracts, on good sanitation and litter management, along with the use of medication or vaccination programmes. In addition to the chemotherapeutic treatment of coccidiosis early disinfection of the poultry houses should be done using various disinfectants for controlling presence of oocysts. The objective of this research was to evaluate in vitro the action of four different coccidicidal disinfectant including (Quaternary ammonium compounds QACs, chlorocresol, glutaraldehyde and kilcox) on oocysts of Eimeria tenella.

Methods: In this study the action of four coccidicidal disinfectant including (Quaternary ammonium compounds QACs, chlorocresol, glutaraldehyde and kilcox) on both sporulated and unsporulated oocysts of Eimeria tenella was evaluated in vitro. E. tenella Oocysts were obtained from naturally infected Egyptian native breed chickens. The oocysts were exposed to the disinfectants at different concentrations and different contact times. The efficacy of the disinfection was assessed by either destruction of sporulated oocyst or inhibition of sporulation. Results: It was observed that the most efficacious disinfectants against unsporulated and sporulated E. tenella oocysts was kilcox followed by chlorocresol, while QACs and, glutaraldehyde were less effective. kilcox sporulation inhibition reached $100 \%$ on unsporulated E. tenella oocysts,and their destructive effect reached $99 \%$ on sporulated oocysts. furthermore, the results showed that both inhibitory and destructive activity of the tested disinfectants was significantly increased by increasing their concentrations and/or the contact time.
\end{abstract}

Key words: Eimeria tenella; chlorocresol; Chickens; sporulation

\section{INTRODUCTION}

Coccidiosis is one of the most serious apicomplexan parasites infecting domestic chickens as well as other fowls. Recent

Corresponding author: Mohamed A. Soliman E-mail address: drmohamed.soliman@mu.edu.eg Present address: Poultry and Fish Diseases Department, Faculty of Veterinary Medicine, Al Minia University, Al Minia 61519, Egypt. reports estimated the direct losses from the disease to exceed one billion us dollars globally in the poultry sector (Allen and Fetterer, 2002). The unicellular protozoa invade the enterocytes of the birds, propagated in a sexual and sexual stages leading to destruction of epithelial lining intestine, bloody diarrhoea, dehydration, poor feed conversion, weight loss and death. 
Chickens can be infected by any of the seven Eimeria species, including Eimeria tenella (E. tenella), Eimeria maxima, Eimeria acervulina, Eimeria necatrix, Eimeria brunette, Eimeria mitis, and Eimeria praecox. In Egypt, E. tenella was the most prevalent species among broiler flocks (Mahareek, 1992). In 2012, AbdelGawad et al., found that $(25.82 \%)$ of 711 samples from Native chickens were infected with E. tenella.

E. tenella oocyst sporulated rapidly outside the infected host. Sporulation can be completed as early as 18 hours after oocysts shedding (Reid et al., 1991). The sporulation depends on many environmental factors, such as: temperature, humidity, and oxygen availability. Viability and infectivity of sporulated oocysts can also depend on the parasite's characteristics, like resistance of disinfectants and adverse field conditions (Fayer, 1980).

Disinfection plays the major role in control process of coccidiosis. Chemical disinfectants that are efficient in inactivating different micro-organisms such as bacteria, fungi or virus do not generally display sufficient coccidiocidal activity (Straberg and Daugschies, 2007). The wall of the oocyst consists of two chemically different layers and the combination of lipids and glycoproteins provides efficient protection of the germinal substance of the oocyst from the action of commonly used disinfectants (Greif et al., 2011). Each chemical disinfectant requires multioptimized conditions to reach its maximum effectiveness such as contact time, concentration and the presence of organic materials that cover and protect oocysts from direct contact, the majority of the effective disinfectants on oocysts are caustic or toxic, inducing dangerous corrosive and health threating side effects upon their use in poultry installations. Studies were carried out worldwide to assess the action of various active principles with disinfectant action over Eimeria spp. oocysts (Fayer, 1980).

The disinfection efficacy (DE) is defined as the sporulation inhibition percentage of oocysts (Daugschies et al., 2002). After in vitro incubation, the coccidiocidal effect of the disinfectant is indicated by its capability of prevent sporulation (Williams, 1997).

This action is observed under two forms on the optic microscope: the oocysts present have lysed wall so, no sporulation occurs, or the wall keeps itself visually preserved, but the oocysts did not sporulate (Daugschies et al., 2002). Though disinfection is widely recognized as an important component of hygiene management (Straberg and Daugschies, 2007), remarkably few papers have been published since then on how to reliably assess the suitability of disinfectants.

This study was conducted to estimate the efficacy of some widely used disinfectant in Egyptian market as coccidiocidal disinfectant on E. tenella oocysts in vitro.

\section{MATERIALS AND METHODS}

\section{Eimeria Oocysts}

Multiple oocysts isolates were obtained from ceci of clinically diseased native breeds chickens (25-40 days old) from different local farms in Assiut, Chickens suffered from depression, ruffled feathers, poor performance and with or without bloody faecal matter. The oocysts harvested from caecal contents and purified by using flotation technique. Oocysts were counted using MacMaster slide, and the number of oocysts was adjusted to 25000 oocysts per ml (Nematollahi et al., 2008).

\section{Morphological identification}

Isolates used for morphological determination were chosen to be mostly consisted of oocysts that are morphologically similar to E.tenella Oocysts morphology and size were determined by measuring length and width 
of 50 similar oocysts using ocular micrometer.

\section{Molecular identification of Eimeria species}

To confirm the presence of E.tenella in the examined isolates, the purified isolates containing aliquots of $\sim 1 \times 10^{6}$ oocysts were taken and oocysts were centrifugated at 2,000 rpm for $2 \mathrm{~min}$. The genomic DNA extracted as per kit protocol, using Gene jet DNA and RNA purification kit (thermo scientific). PCR with the SCAR primers for E. tenella; $\mathbf{F}$
CCGCCCAAACCAGGTGTCACG and $\mathbf{R}$ CCGCCCAAACATGCAAGATGGC were carried out with a thermocycler adjusted as follow: Standardized cycling conditions consisted of initial denaturation: $96{ }^{\circ} \mathrm{C}$ for 5 min, (denaturation: $94{ }^{\circ} \mathrm{C}$ for $1 \mathrm{~min}$, annealing: $62{ }^{\circ} \mathrm{C}$ for $2 \mathrm{~min}$, extension: 72 ${ }^{\circ} \mathrm{C}$ for $1 \mathrm{~min}$ ) for 30 cycles and Final extension: $72{ }^{\circ} \mathrm{C}$ for $7 \mathrm{~min}$. All PCR products were analyzed by separation on $1.5 \%$ agarose gel in TAE buffer at $100 \mathrm{~V}$ for $30 \mathrm{~min}$, were stained with ethidium bromide, and examined under UV light.

\begin{tabular}{ccc}
\hline Primer sequences (5-3) & Amplicon size (bp) & Annealing temperature \\
\hline CCGCCCAAACCAGGTGTCACG & 539 & $60^{\circ} \mathrm{C}$ \\
CCGCCCAAACATGCAAGATGGC & & \\
\hline
\end{tabular}

\section{Disinfectants:}

Four different disinfectants were obtained from Kilco company for veterinary disinfectants (Kilco International Ltd, Northern Ireland) with a different active principle each as follow:

Chlorocresol was obtained as $100 \%$ concentrated crystals, then two dilutions $10 \%$ and $20 \%$ were prepared by adding $10 \mathrm{gm}$ of chlorocresol to $100 \mathrm{ml}$ Ether and by adding $20 \mathrm{gm}$ of chlorocresol to $100 \mathrm{ml}$ Ether, respectively.
Quaternary ammonium compounds (QACs) was obtained as $100 \%$ concentrated solution, then two dilutions $2 \%$ and $4 \%$ were prepared by adding $2 \mathrm{ml}$ of QACs to $100 \mathrm{ml}$ water and by adding $4 \mathrm{ml}$ of QACs to $100 \mathrm{ml}$ water respectively.

Glutaraldehyde $(50 \%)$ solution was used at concentrations $2 \%$ and $4 \%$. kilcox Extra (a commercial product from Kilco company), it was used at concentrations $2 \%$ and $4 \%$. Contains.

\begin{tabular}{ll}
\hline Para chloro meta Chlorocresol & $100 \mathrm{~g} / \mathrm{kg}$. \\
\hline Benzalkonium Chloride & $100 \mathrm{~g} / \mathrm{kg}$. \\
\hline Glutaraldehyde & $150 \mathrm{~g} / \mathrm{kg}$. \\
\hline
\end{tabular}

Isolates were divided into two Parts, first was subjected to different concentrations and contact times of the disinfectants, and then allowed to sporulate in potassium dichromate $(2.5 \%)$ in petri-dishes.

The second part was allowed to sporulate by adding amount of potassium dichromate $(2.5 \%)$ in petri-dishes. The Petri-dishes were semi-covered and kept at room temperature $\left(25-28^{\circ} \mathrm{C}\right.$ ) for 3-5 days (Conway and McKenzie, 2007) and then subjected to different concentrations and contact times to the disinfectants after sporulation to evaluate the destructive activity of each disinfectant.

Both sporulated and unsporulated oocysts were subjected to the following protocols according to (Junior et al., 2007). 


\begin{tabular}{ccc}
\hline Disinfectant & Concentration & Time of exposure \\
\hline \multirow{2}{*}{ Chlorocresol } & $10 \%$ \\
\cline { 2 - 2 } Quaternary ammonium compounds & $20 \%$ \\
\cline { 2 - 3 } & \multirow{2}{*}{30,120 minutes } \\
\cline { 2 - 3 } Glutaraldehyde $(50 \%)$ & $4 \%$ \\
\hline \multirow{2}{*}{ kilcox } & $2 \%$ \\
\hline
\end{tabular}

\section{sporulation percentage and sporulation inhibition activity}

Sporulation percentage (SP) was calculated after 7 days to get the percentage of Sporulation inhibition activity (IA) of the oocysts and were calculated according to (junior et al., 2007)
$\mathrm{IA} \%=\{$ (sporulation $\%$ of control sporulation $\%$ of disinfectant treated oocysts) X 100\} sporulation \% of control.

\section{RESULTS}

On gross lesion examination of the intestinal tract especially the two caecal lesions showed haemorrhages \& clotted blood in caecal pouches. Figure (1)

\section{figure legends, and tables:}

Figure 1: Two caeci of infected chicken showing bloody contents.

Figure 2: Eimeria tenella oocysts in wet smear (10x objective lens).

Figure 3: lane 4 control positive for E. tenella 539bp and lane 5 pool positive for (E. tenella 539bp).

Figure 4: inhibitory activity of disinfectants on unsporulated oocysts.

Figure 5: effect of disinfectants on sporulated oocysts.

Table 1: The inhibitory activity of disinfectants on unsporulated oocysts.

Table 2: The destructive activity of disinfectants on sporulated oocysts.

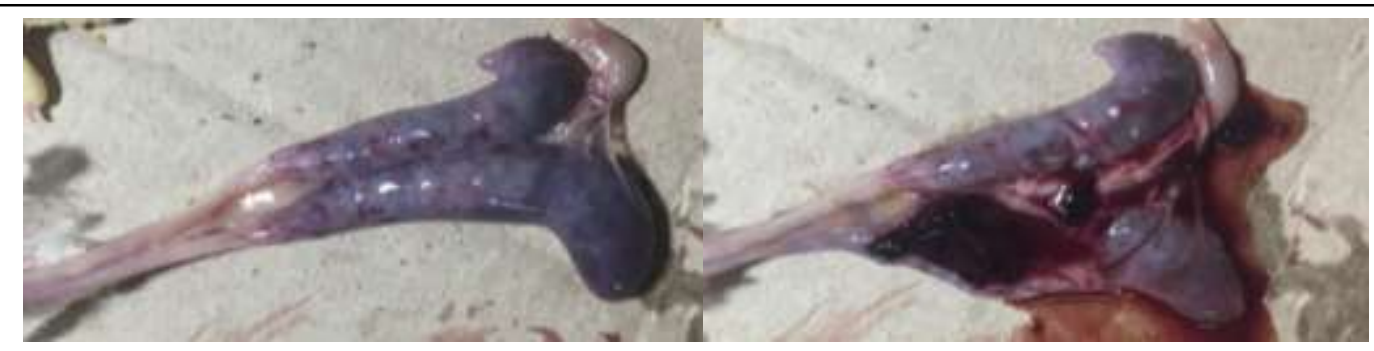

Figure (1): Two caeci of infected chicken showing bloody contents.

\section{Morphological identification:}

Microscopical identification of Eimeria oocyst species revealed that $90.25 \%$ of collected samples were found infected with E. tenella. Figure (2) 


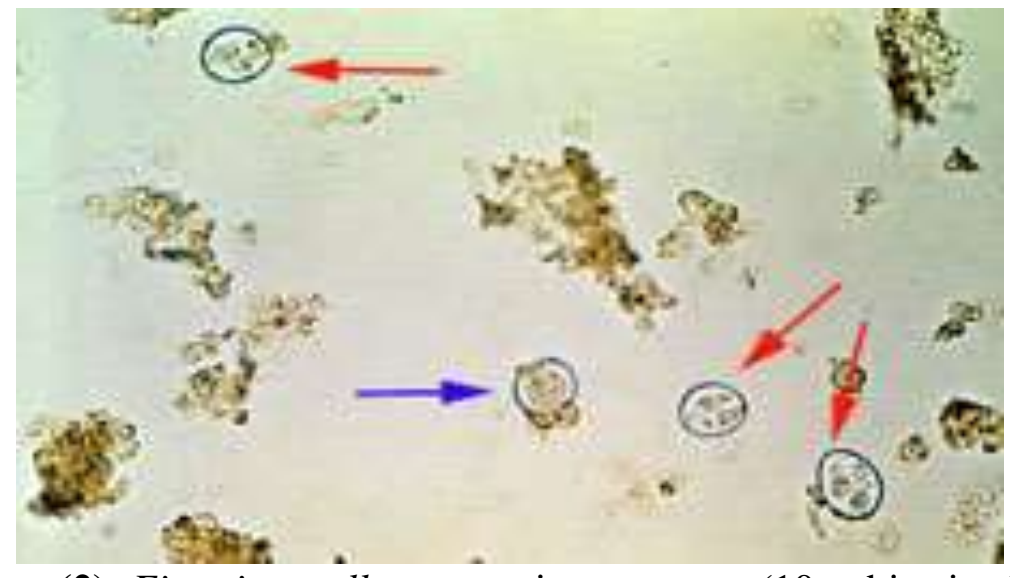

Figure (2): Eimeria tenella oocysts in wet smear (10x objective lens)

Molecular identification of Eimeria detection of the amplified fragment (539 bp). species:

The presence of E. tenella oocysts in the Figure (3) examined samples was confirmed by the

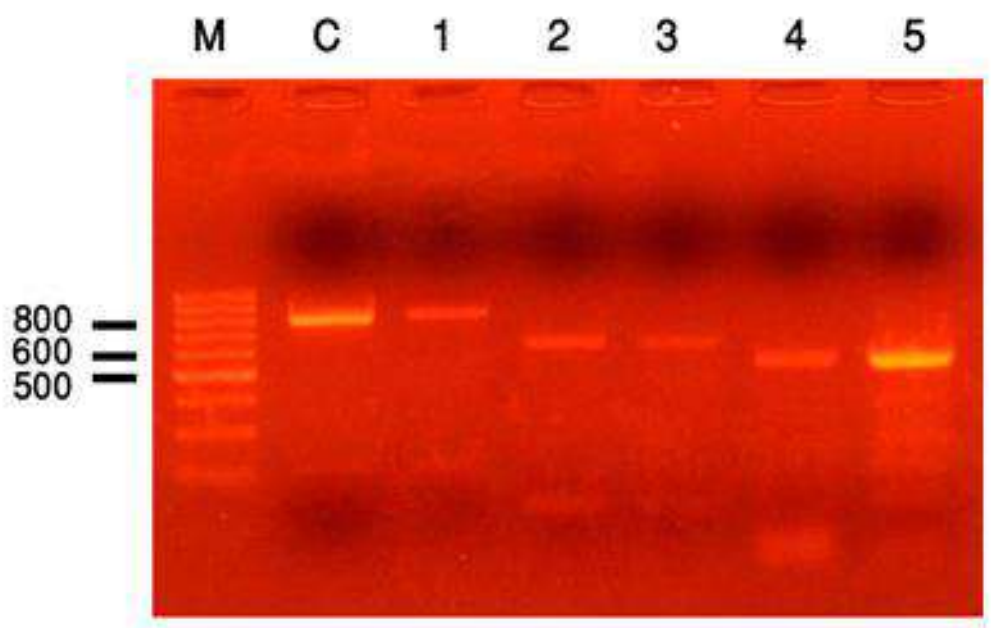

Figure (3): lane 4 control positive for E. tenella 539bp and lane 5 pool positive for (E. tenella $539 \mathrm{bp})$

The efficacy of disinfectants on E.tenella oocysts:

The inhibitory and destructive effect of different disinfectants on unsporulated and sporulated E. tenella oocysts were tabulated in tables $1 \& 2$.

Table 1: The inhibitory activity (IA) of disinfectants on unsporulated oocysts.

\begin{tabular}{|c|c|c|c|c|c|c|c|c|c|c|c|c|c|c|c|c|c|c|}
\hline \multirow{3}{*}{ C.T. } & \multicolumn{4}{|c|}{ kilcox } & \multicolumn{4}{|c|}{ QACs } & \multicolumn{4}{|c|}{ glutaraldehyde } & \multicolumn{4}{|c|}{ chlorocresol } & \multicolumn{2}{|c|}{ control } \\
\hline & \multicolumn{2}{|c|}{$2 \%$} & \multicolumn{2}{|c|}{$4 \%$} & \multicolumn{2}{|c|}{$2 \%$} & \multicolumn{2}{|c|}{$4 \%$} & \multicolumn{2}{|c|}{$2 \%$} & \multicolumn{2}{|c|}{$4 \%$} & \multicolumn{2}{|c|}{$10 \%$} & \multicolumn{2}{|c|}{$20 \%$} & & \\
\hline & SP $\%$ & IA $\%$ & $\begin{array}{c}\mathrm{SP} \\
\%\end{array}$ & $\begin{array}{c}\mathrm{IA} \\
\%\end{array}$ & $\mathrm{SP} \%$ & $\mathrm{IA} \%$ & $\mathrm{SP} \%$ & $\begin{array}{c}\text { IA } \\
\%\end{array}$ & $\begin{array}{c}\mathrm{SP} \\
\%\end{array}$ & $\begin{array}{c}\text { IA } \\
\%\end{array}$ & $\begin{array}{l}\mathrm{SP} \\
\%\end{array}$ & $\begin{array}{c}\text { IA } \\
\%\end{array}$ & $\begin{array}{l}\mathrm{SP} \\
\%\end{array}$ & $\begin{array}{c}\text { IA } \\
\%\end{array}$ & $\begin{array}{c}\text { SP } \\
\%\end{array}$ & $\begin{array}{c}\text { IA } \\
\%\end{array}$ & $\begin{array}{l}\mathrm{SP} \\
\%\end{array}$ & $\begin{array}{l}\mathrm{IA} \\
\%\end{array}$ \\
\hline $\begin{array}{c}30 \\
\text { min. }\end{array}$ & 27.6 & 97.3 & 2 & 99 & 24.7 & 76.3 & 11.9 & 88.1 & 38.3 & 61.7 & 18.2 & 81.8 & 13.3 & 86.7 & 7.3 & 92.7 & 99 & 0 \\
\hline $\begin{array}{l}120 \\
\mathrm{~min}\end{array}$ & 20.1 & 98 & 0.3 & 100 & 8.2 & 91.8 & 6.2 & 93.9 & 23.4 & 76.6 & 11 & 94.8 & 9.3 & 90.7 & 6 & 94 & 99 & 0 \\
\hline
\end{tabular}

C.T. $=$ contact time $\quad$ SP\% $=$ sporulation percentage $\quad$ IA\% $=$ inhibitory activity 


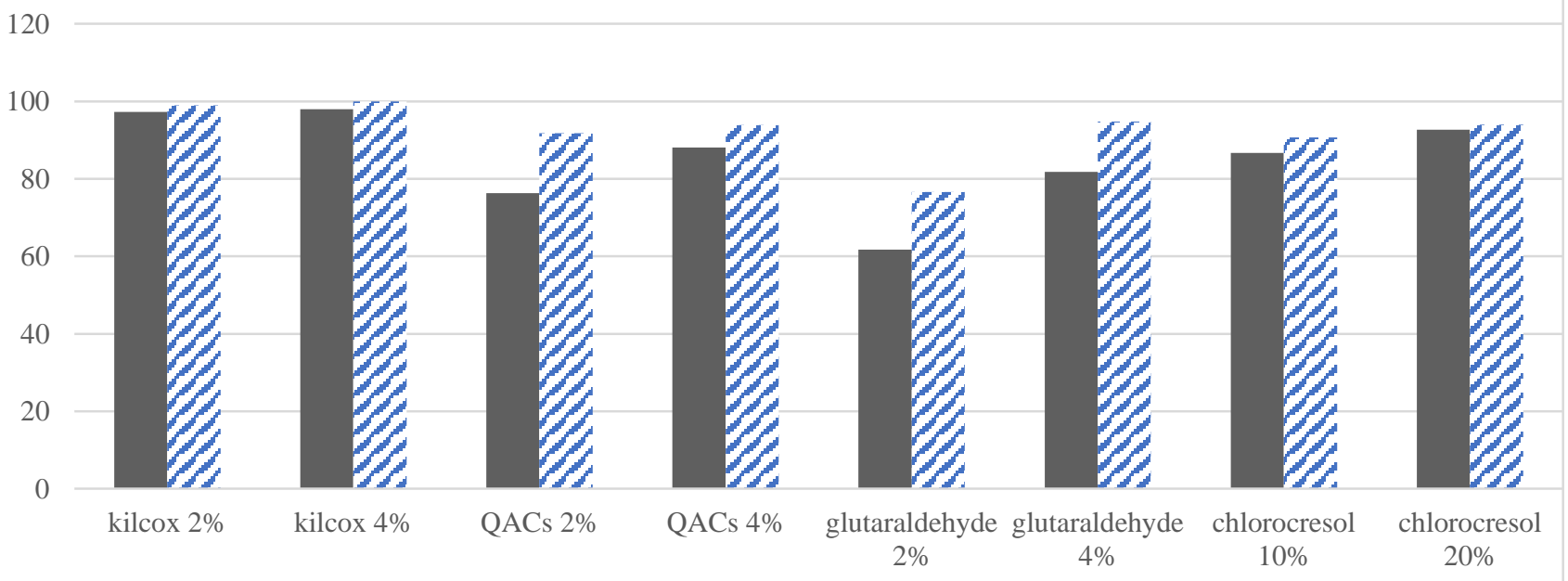

- $30 \mathrm{~min} . \quad 120 \mathrm{~min}$.

figure 4:inhibitory activity of disinfectants on unsporulated oocysts

Results in Table (1) illustrated that the IA of four disinfectants against unsporulated E. tenella oocysts, kilcox (4\%) was highly effective against unsporulated $E$. tenella oocysts at C.T of 30 and 120 minutes where the IA reached $99 \%$ and $100 \%$, respectively. While the effect of lower concentration ( $2 \%$ ) for C.T of 30 and 120 minutes reached $97.3 \%$ and 98 $\%$, respectively.

The IA of Quaternary ammonium compound (QACs) on E. tenella unsporulated oocysts at $2 \%$ solution for 30 and 120 minutes C.T. resulted $76.3 \%$ and $91.8 \%$ IA and when we used $4 \%$ solution of QACs recorded good efficacy $88.1 \%$ and $93.9 \%$ respectively.

The effect of $2 \%$ solution of Glutaraldehyde at 30 and 120 minutes C.T. against the unsporulated oocysts resulted $61.7 \%$ and $76.6 \%$ IA. And usage of $4 \%$ solution of Glutaraldehyde resulted $81.8 \%$ and $94.8 \%$.

The usage of $10 \%$ solution of chlorocresol against unsporulated oocysts at 30 and 120 minutes C.T. resulted $86.7 \%$ and $90.7 \%$ IA respectively, at $20 \%$ conc. the results were $92.7 \%$ and $94 \%$.

Table 2: The destructive activity of disinfectants on sporulated oocysts

\begin{tabular}{cccccccccc} 
& \multicolumn{2}{c}{ kilcox } & \multicolumn{2}{c}{ QACs } & glutaraldehyde & chlorocresol & control \\
\cline { 2 - 9 } C.T. & $2 \%$ & $4 \%$ & $2 \%$ & $4 \%$ & $2 \%$ & $4 \%$ & $10 \%$ & $20 \%$ & \\
\hline 30 min. & 72.4 & 93 & 53.6 & 59.2 & 21.5 & 66.8 & 60 & 85 & 2 \\
\hline 120 min. & 79.9 & 99 & 66.4 & 69.2 & 49.2 & 89 & 77 & 98 & 2 \\
\hline
\end{tabular}




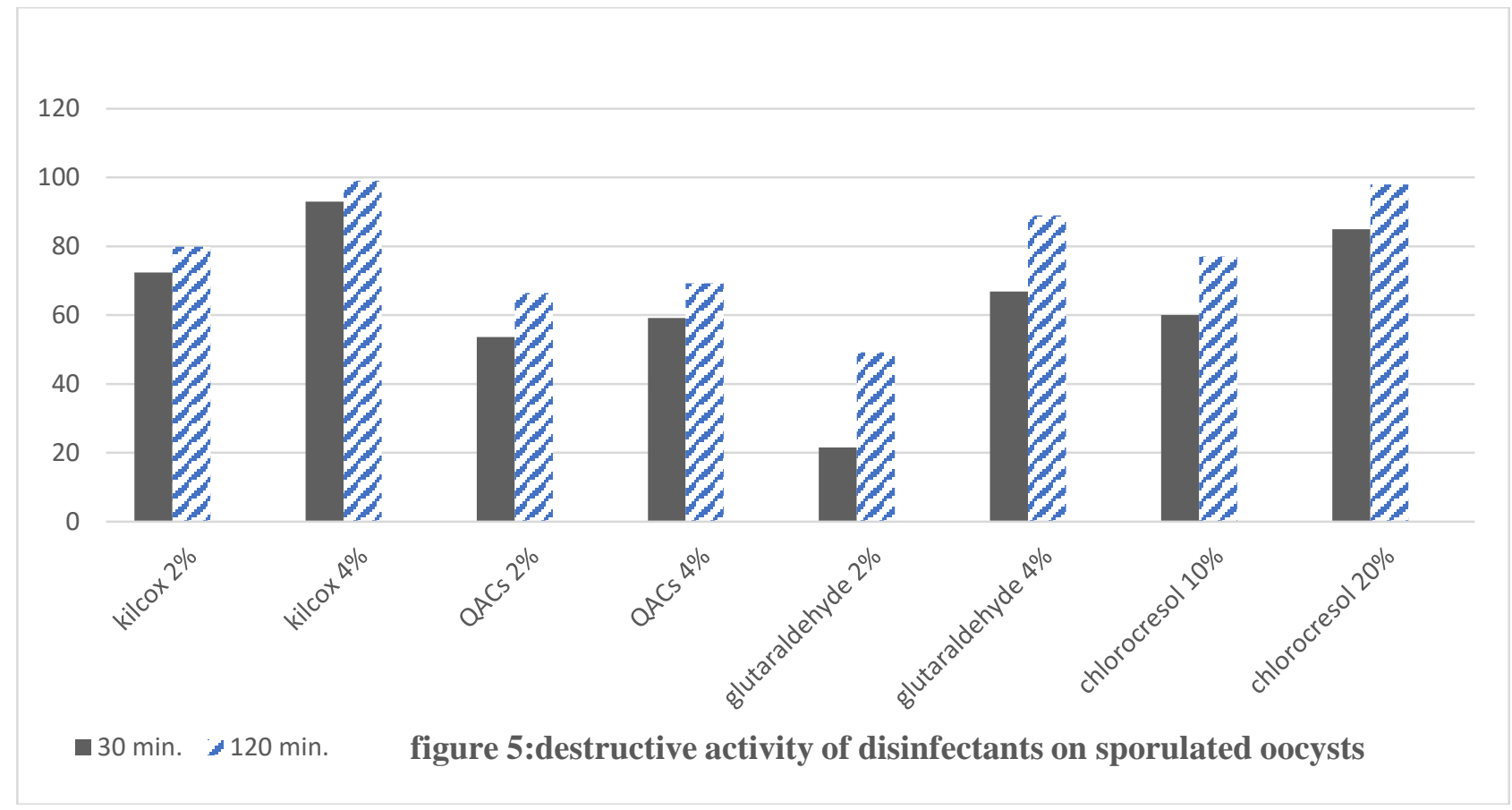

On other hand the obtained results in table (2) documented the destructive activity of the examined disinfectants on sporulated oocysts, the destructive effect of kilcox concentrations $4 \%$ against sporulated oocysts at 30 and 120 minutes reached 93 $\%$ and $99 \%$, respectively.

Usage of 2\% QACs solution at 30 and 120 minutes C.T. their (DE) was $53.6 \%$ and $66 \%$, consequently, while the usage of $4 \%$ solution of QACs at 30 and 120 minutes C.T. resulted in (DE) $59 \%$ and $69 \%$, respectively.

$2 \%$ solution of glutaraldehyde at 30 and 120 minutes C.T. able to induce lysis of $21.5 \%$ and $49 \%$ of treated oocysts, respectively. while at $4 \%$ conc. 30 and 120 minutes C.T. the result were $66.7 \%$ and $89 \%$, respectively.

The usage of $10 \%$ solution of chlorocresol at 30 and 120 minutes C.T. resulted in destruction activity by $60 \%$ and $77 \%$, respectively. At $20 \%$ conc. the results were $85 \%$ and $98 \%$.

The findings obtained illustrated the powerful effect of Kilcox against sporulated oocysts.

\section{DISCUSSION}

From the viewpoint of coccidia control inactivation of exogenous stages of parasites is important for reducing infection pressure and protecting hosts from disease. Many commercial chemical disinfections eliminate bacteria or virus particles but don't have inadequate or unknown anticoccidial properties (Daugschies et al., 2013).

The present research tested the ability of four chemical disinfectants to stop oocysts sporulation after in vitro incubation, and the effect of concentration and contact time (C.T) on efficacy of tested disinfectants against E. tenella oocysts.

Firstly, it was observed that the effect of different disinfectants on unsporulated oocycts was nearly convergent this may be due to absence of the double cell wall which facilitate the action of disinfectants, firstly Chlorocresol in high concentration was highly effective against unsporulated E. tenella oocysts at C.T of 30 and 120 minutes where the IA reached $99 \%$ and $100 \%$, respectively. The obtained results revealed also the powerful destructive 
effect of kilcox concentrations 4\% against sporulated oocysts at 30 and 120 minutes reached $93 \%$ and $99 \%$, respectively.

Concerning to Quaternary ammonium compound (QACs): its IA on E. tenella unsporulated oocysts at $4 \%$ solution recorded good efficacy $88.1 \%$ and $93.9 \%$ respectively. additionally, it was found that the efficacy was improved as the contact time increased. This result may be due to QACs were lipophilic compounds so; it may work on the oocyst wall so increasing concentration and/or CT leads to increasing of IA that agreed with (Bessems, 1998). Also, National Seafood HACCP Alliance, (2000) mentioned that QACs required a relatively long contact time to achieve significant kill.

In contrast, the disinfection efficacy (DE) of QACs on sporulated oocysts is much lower than other disinfectants.

Data tabulated in table (1) also showed that the effect of high concentration $4 \%$ solution of Glutaraldehyde against the unsporulated oocysts having good efficacy against the unsporulated oocysts. regarding its effect on sporulated oocysts, it was observed that the efficacy was increased by increasing the contact time, as the best result was obtained at 120 minutes contact time.

The usage of $20 \%$ solution of chlorocresol against both unsporulated and sporulated oocysts assessed good efficacy and powerful effect of chlorocresol. Similar results were obtained by (Straberg and Daugschies, 2007) and (You and Korean, 2014) who observed that cresol effectively inhibited sporulation up to $85.5 \%$. While the obtained results were higher than that obtained by Oliveira, et al. (2004) who treated the oocysts of $E$. tenella, $E$. acervulina and E. maxima species with phenol $10.5 \%+$ Chlorocresol $10.5 \%$ at exposure time of 30 minutes and recorded only $7.7 \%$ IA. Daugschies et al. (2007) showed completely destroyed oocysts after a contact time of 90 min or more with the cresol-based products.

The present study cleared presence of differences between effect of the most tested disinfectants against unsporulated and sporulated oocysts. Williams (1997) indicated that unsporulated oocysts are more susceptible to disinfectants than sporulated one.

According to Daugschies et al. (2002) an inhibitory activity (IA) of at least $95 \%$ was required for certification of sufficient disinfecting efficacy by the German Veterinary Society. For which, Chlorocresol is considered the best chemical disinfectant against unsporulated and sporulated E. tenella oocysts in vitro in the present study.

\section{CONCLUSION}

From this study, it can be concluded that, a) disinfectant efficiency was conditioned by the disinfectant concentration and its exposure time to the oocysts. b) the most effective disinfectants against unsporulated and sporulated E. tenella oocysts was kilcox followed by chlorocresol, while QACS and, glutaraldehyde was less effective. c) in practical application of any disinfectant we should care to other environmental factors that can interact with the effect of disinfectants.

\section{CONFLICT OF INTEREST STATEMENT}

The authors declare that they have no conflict of interest.

\section{ACKNOWLEDGMENT}

The authors appreciated many greats for prof. dr. Mohsen Arafa for continuous helping. 


\section{REFERENCES}

Abd El-Gawad, A.; Olfat A.; El-Massry, Aida, A. and Al-Aziz, MS. (2012): Studies on Coccidia of Egyptian Balady Breed Chickens. Life Sci., 9 (3): 568-576.

Allen, PC. and Fetterer, RH. (2002): Recent Advances in Biology and Immunobiology of Eimeria Species and in Diagnosis and Control of Infection with These Coccidian Parasites of Poultry. Clin. Microbiol. J. 15 (1), 58-65.

Bessems, E. (1998): The effect of practical conditions on the efficacy of disinfectants. Int. Biodeterioration \& Biodegradation 41: 177-183.

Conway, DP. and McKenzie Elizabeth, M. (2007): Poultry Coccidiosis. Diagnostic and Testing Procedures. 3rd ED, Blackwell Publishing Professional.

Daugschies, A.; Bangoura, B. and Lendner, M. (2013): Inactivation of Exogenous Endoparasite Stages by Chemical Disinfectants: Current State and Perspectives. Parasitol Res. 2013 Mar; 112(3): 917-32.

Daugschies, A.; Agneessens, J.; Goossens, L.; Mengel, H. and Veys, P. (2007): The effect of a metaphylactic treatment with diclazuril (Vecoxan ${ }^{\circledR}$ ) on the oocyst excretion and growth performance of calves exposed to a natural Eimeria infection. Veterinary Parasitology; 149: 199-206.

Daugschies, A.; Bose, R.; Marx, J.; Teich, $K$. and Friedhoff, KT. (2002): Development and application of standardized assay for chemical disinfection of coccidia oocysts. Veterinary Parasitology, v. 103, n. 4, p. 299-308.

Fayer, R. (1980): Epidemiology of protozoan infections: The Coccidia. Veterinary Parasitology, v.6, n. 1-3, p. 75-103.

Greif, G.; Froyman, R.; Ortiz, C.; Renner, GF.; Exner, O.; Schlegel, D. and matysiak, R. (2011): United States.
Patent Application Publication. Disinfectants. US 2011/0086823 AI.

Junior, JS.; Bogado, AL.; Da Cunha, TC. and Garcia, JL. (2007): In vitro evaluation of the disinfection efficacy on Eimeria tenella unsporulated oocysts isolated from broilers. Rev. Bras. Parasitol. Vet., 16(2): 67-71.

Mahareek, RM. (1992): Therapeutic Efficacy of Anticoccidial Drugs. M.V.Sc. Thesis, Faculty of Vet. Med. Assiut University.

National Seafood HACCP Alliance (2000): Sanitation Control Procedures for Processing Fish and Fishery Products, First edition January 2000, 203 pages.

Nematollahi, A.; Moghaddam, Gh. and Niyazpour, F. (2008): Prevalence of Eimeria sp. among broiler chicks in Tabriz (Northwest of Iran). Res. J. poult. Sci., 2 (3): 72-74.

Oliveira, MR.; Longhi, E.; Ono, LM.; Zulpo, DL. and Peretti, J. (2004): Efic $\tilde{A}_{i}$ cia de inibi $\tilde{A} \S \tilde{A} £ o$ da esporulaÃß̃̃£oemoocistos de Eimeria de avestratados com desinfetantes de usocomercial. In: ENCONTRO ANUAL DE INICIA $\tilde{\ddagger}+\tilde{A} f O$ CIENTÃ • FICA, 13, 2004, Londrina. Anais. Londrina: UEL, 2004.

Reid, XM.; Mcdougald, LR.; Calnek, BW.; Barnes, HJ.; Beard, CW.; Eid, WM. and Yoder, JR. (1991): Coccidiosis. In Diseases of Poultry, 9 ed. Ames: Iowa State University Press. 780-792.

Straberg, E. and Daugschies, A. (2007): Control of Piglet Coccidiosis by Chemical Disinfection with a CresolBased Product (Neopredisan) Para. sitol. Res. 101: 599-604.

Williams, RB. (1997): Laboratory tests of phenolic disinfectants as oocysticides against the chicken coccidium Eimeria tenella. Veterinary Record, v. 141 , n. 17 , p. 447-448.

You, M. and Korean, J. (2014): Suppression of Eimeria tenella sporulation by disinfectants. Parasitol. J. 52(4): 435-8. 


\section{كفاءة أربع مطهرات ضد معزولات الايميريا تينيلا من الاجاج المصري (تقييم معملي) شيم الشري ، محد /حد علي ، محد عادل سليمان ، مديحة درويش ، عمر أمين}

E-mail: drmohamed.soliman@mu.edu.eg Assiut University web-site: www.aun.edu.eg

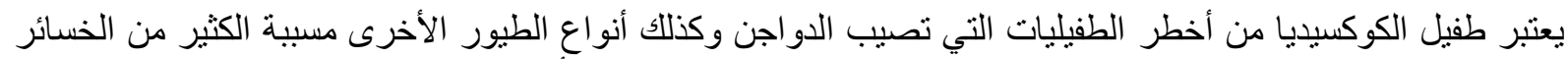

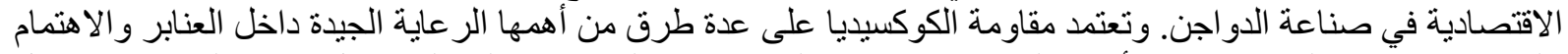

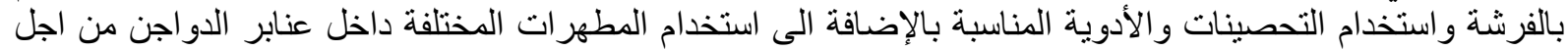

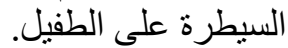

الهدف من هذه الدراسة هو التقييم المعملي لكفاءة أربعة مطهرات وكئ وكي مركبات رباعي الامونيوم والجلوتر الدهيد

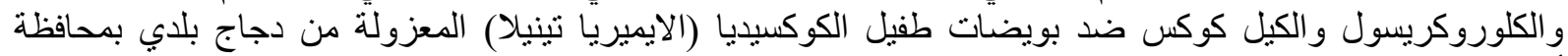

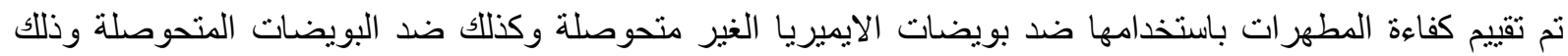

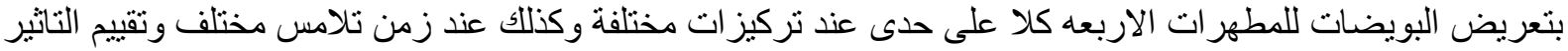

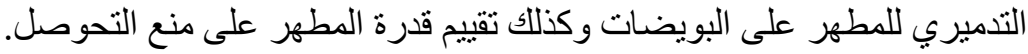

وكانت النتائج كلاتي أفضل النتائج حصلنا عليها عند استخدام الكيل كوكس ثم الكلوروكريسول يتبعهه مركبات ربات رباعي

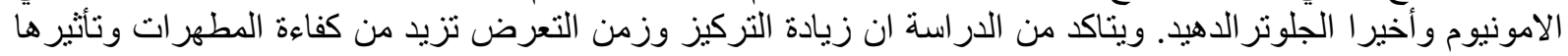
على بويضات الطفيل. 